\title{
Badania przemian japońskiego filmu awangardowego. Od Terayamy do audiowizualnego eksperymentu po 2000 roku
}

\begin{abstract}
Wstęp
Japońskie kino awangardowe, powiązane z teatrem ulicznym i działaniami performatywnymi, stanowi jednocześnie konglomerat wpływów zachodniej sztuki wizualnej i przykład unikalnej w skali światowej jakości estetycznej. Połączenie inspiracji dokonaniami reżyserów zachodnich z poszukiwaniem odpowiedzi na przemiany społeczno-polityczne zachodzące w Japonii doprowadziło do wykształcenia się niepowtarzalnego stylu japońskich twórców. Różnorodność form artystycznych i ich głębokie zakorzenienie w rodzimej kulturze Japończyków pozwala spojrzeć na awangardę filmową w Kraju Kwitnącej Wiśni jako na zjawisko wychodzące poza ramy wyznaczone przez niezależne działania twórców zachodnich.

Głównym celem badań awangardowego kina japońskiego (w tym wchodzącego w jego zakres filmu eksperymentalnego) jest ukazanie różnorodności zjawisk wpisujących się w ramy powyższego terminu oraz potrzeba ich klasyfikacji i opisu w językach innych niż japoński. Dlatego też analiza kierunków rozwoju oraz przemian japońskiego kina awangardowego wymaga skonstruowania podstawy pojęciowej pozwalającej na podkreślenie różnic i cech wspólnych awangardy
\end{abstract}


wschodniej oraz zachodniej, a także opisanie zakresu przenikania się wpływów obydwu kręgów kulturowych. Badając japońskie kino awangardowe, nie można zapomnieć o potrzebie wskazania głównych tematów poruszanych przez twórców oraz umiejscowienia ich we właściwym kontekście historycznym. W związku z tym, podczas opisu prezentowanego zjawiska przydatne wydają się interdyscyplinarne metody badawcze, związane z praktyką filmoznawczą, historyczną, a także badaniami nad komunikacją kulturową.

Celem niniejszego artykułu jest przedstawienie zakresu materiału badawczego, wybranych metod pomocnych w trakcie badań oraz stworzenie zarysu koncepcji spojrzenia na japoński film awangardowy. Jako ilustracje przywołanych zagadnień posłużą wybrane przykłady sztuk audiowizualnych, zaczerpnięte z różnych epok kinematografii japońskiej.

\section{Badania japońskiej awangardy na tle polskiego filmoznawstwa: cele badawcze}

Japoński film awangardowy oraz eksperyment audiowizualny do tej pory doczekały się niewielu opracowań w języku polskim ${ }^{1}$. O najbardziej znanym, zarówno w Japonii, jak i na Zachodzie, artyście tworzącym w latach 70., Shūjim Terayamie ${ }^{2}$, powstały zaledwie artykuły w czasopismach naukowych (Karolak 2014: 137-151), rozdziały w drukach zwartych (Loska 2013: 52-72) oraz publikacje w serwisach internetowych poświęconych Japonii (Karolak 2013). Innym rozpoznawalnym w Polsce twórcą niezależnym, który w unikalny sposób zinterpretował dokonania japońskiej awangardy i zaprezentował jej technologiczną, cyberpunkową wersję, jest Shinya Tsukamoto. Jednak, mimo że jego film Tetsuo - człowiek z żelaza ${ }^{3}$ wyznaczył kierunek dalszego rozwoju nowego gatunku filmowego, Tsukamoto doczekał się na gruncie polskim zaledwie jednego dłuższego rozdziału w monografii zbiorowej (Kiejziewicz 2014: 81-97). Podobnie nieopisane pozostają dokonania współczesnych eksperymentatorów - artystów młodego pokolenia, tworzących po 2000 roku. Do tej pory, w formie krótkiego artykułu w języku angielskim, ukazało się jedno studium na temat wybranych dzieł (Kiejziewicz 2016: 147-

\footnotetext{
${ }^{1}$ Stan na wrzesień 2016 roku.

${ }^{2}$ Twórczość Terayamy została opisana w języku angielskim przez takich badaczy jak Carol Fisher Sorgenfrei, Steven Ridgely, czy Keiko Courdy.

${ }^{3}$ Tetsuo - człowiek z żelaza (Tetsuo, 1989), Shinya Tsukamoto.
} 
156). Komentarz do wybranych prac młodych japońskich twórców sztuk audiowizualnych, takich jak performans, instalacje audiowizualne, zapisy filmowe oraz instalacje przestrzenne, można także odnaleźć w materiałach wydanych przez Centrum Sztuki WRO we Wrocławiu w ramach wystawy ECO EXPANDED CITY 2016 (majgrudzień 2016) ${ }^{4}$. Jednakże, foldery zawierające opisy dokonań takich artystów i artystek, jak Ai Hasegawa, Kazuhiro Goshima, Aki Inomata, Makoto Murayama czy cieszącego się ogromnym dorobkiem twórczym Takahiko Iimury, nie stanowią analizy akademickiej i mogą być traktowane tylko jako materiał do dalszych badań.

Dlatego też głównym celem badań nad japońskim filmem awangardowym jest jego popularyzacja na gruncie polskim, co z kolei ma prowadzić do umożliwienia odbiorcom zapoznania się $\mathrm{z}$ marginalizowanymi obszarami kultury japońskiej, a w konsekwencji wytworzenia nowego sposobu postrzegania sztuk audiowizualnych Kraju Kwitnącej Wiśni. Opisanie i analiza słabo rozpoznawalnych dokonań eksperymentatorów wiąże się również z ukazaniem różnorodności zjawisk składających się na szeroko rozumiane „awangardowe podejście" w sztuce filmowej. Charakterystycznymi cechami japońskiej awangardy, podobnie jak miało to miejsce w przypadku ruchów zachodnich, są poszukiwania przez artystów nowych form wyrazu oraz manifestowanie potrzeby reinterpretacji tradycji kulturowej, przy jednoczesnym wykorzystaniu dobrodziejstw najnowszych osiągnięć technologicznych. Warto zauważyć, że sztuka zachodnia była (i nadal jest) bogatym źródłem inspiracji dla twórców japońskich, więc opis ich dokonań jest jednocześnie procesem odtwarzania drogi transferu treści artystycznych z różnych zakątków świata na grunt japoński. Z drugiej strony, dokonaniami Japończyków fascynowali się również Polacy, na czele z Tadeuszem Kantorem, odwołującym się do twórczości Terayamy (Karolak 2013). Popularyzacja zjawisk artystycznych spoza głównego nurtu sztuki prowadzi także do głębszego zrozumienia przemian społecznych zachodzących w powojennej Japonii. Sztuka niezależna w Kraju Kwitnącej Wiśni od lat 60. stanowiła komentarz i krytykę bieżących wydarzeń politycznych, a funkcjonowanie poza głównym obiegiem treści pozwalało artystom niezależnym na surową ocenę problemów oraz wydarzeń, które oficjalnie nie były podejmowane przez kulturę popularną oraz media. Obecnie niektórzy z młodych eksperymentatorów, nawiązując do krytycznej roli niezależnego artysty, nadal podejmują $\mathrm{w}$ swoich obrazach filmowych pro-

\footnotetext{
${ }^{4}$ Centrum Sztuki Wro. 2016. ECO EXPANDED CITY (folder wystawowy).
} 
blemy takie jak alienacja jednostki w przestrzeni miejskiej ${ }^{5}$ czy katastrofy ekologiczne ${ }^{6}$, zauważalnie odcinając się od treści politycznych.

\section{Ramy pojęciowe i metody badawcze}

Istotnym elementem badania japońskiej awangardy jest skonstruowanie ram pojęciowych właściwie klasyfikujących obserwowane zjawiska. Warto zauważyć, że przenikanie się tematyki i źródeł inspiracji między Wschodem a Zachodem doprowadziło do wytworzenia się na gruncie japońskim całkiem nowej jakości, co związane jest z połączeniem tradycji estetycznej Kraju Kwitnącej Wiśni z dokonaniami Zachodu. Dlatego też, pisząc o japońskiej odmianie awangardy, należy odnieść się do twórczego przekształcenia pierwotnych wschodnich kategorii estetycznych $^{7}$ (Kubiak Ho-Chi 2009: 39-68), a nie do pojęć estetyki zachodniej. $\mathrm{Z}$ drugiej strony, analizując sztukę audiowizualną, nie można odciąć się od aparatu badań filmoznawczych i postrzegania kina japońskiego przez pryzmat zachodniej teorii filmu ${ }^{8}$. Ponadto, opisując dokonania awangardy japońskiej, a szczególnie jej eksperymentalnej gałęzi, warto poszerzyć badania o odniesienia do teorii mediów funkcjonujących na Zachodzie. Wyjątkowo trafna w kontekście działań niezależnych, poszukiwania formy wyrazu i próby określenia struktur powiązań różnych mediów wydaje się tutaj koncepcja różnicy między formą a medium w ujęciu Niklasa Luhmanna (Mersch 2010: 205-216). . Filozof odchodzi

${ }^{5}$ Zob. Inne miasta (Different Cities, 2006), Kazuhiro Goshima.

${ }^{6}$ Przykładem takiego krytycznego komentarza może być instalacja audiowizualna z elementami performatywnymi Sound of a million insects, light of a thousand stars (2014) stworzona przez Tomonariego Nishikawę. Artysta odnosi się w niej do katastrofy elektrowni w Fukushimie i niedopowiedzeń, jakich dopuszczał się rząd japoński w związku z poziomem skażenia terenów wokół reaktora.

${ }^{7}$ Przykładami takich japońskich kategorii estetycznych mogą być mono no aware (świadomość przemijania, odczucie patosu rzeczy codziennych) lub wabi (akceptacja prostoty i niedoskonałości rzeczy, „szlachetny minimalizm”).

${ }^{8}$ Zachodnim badaczem posiadającym duży dorobek w dziedzinie badania kina japońskiego jest historyk filmu Donald Richie. Autor ma na swoim koncie nie tylko publikacje naukowe, ale również ponad trzydzieści filmów eksperymentalnych, z których wiele nawiązuje do kultury i estetyki japońskiej.

${ }^{9}$ Autor opracowania, przytaczając koncepcje Luhmanna, zauważa, że „[...] medium i forma okazują się być wzajemnie powiązane, składając się z tych samych elementów, które różnią się jedynie pod względem stopnia ich nieuporządkowania albo uporządkowania.[...] Media i formy nie są same czymś konkretnym, lecz powstają i znikają jedynie w stałym procesie 
w swoich przemyśleniach od charakteryzujących inne teorie aparatów i kodów na rzecz badania braku stałych powiązań pomiędzy konkretną formą i medium (Mersch 2010), co doskonale oddaje dynamiczny charakter przemian wewnątrz nowego japońskiego filmu eksperymentalnego.

Ze względu na różne sposoby manifestowania podejścia awangardowego wśród twórców japońskich oraz złożoność zjawiska, przenikanie się wielu obszarów sztuki, a także ilość podejmowanych przez artystów tematów, podczas badań niezbędne jest wykorzystanie interdyscyplinarnych metod badawczych. Stworzenie ram pojęciowych opisujących zjawisko może nastąpić dzięki zastosowaniu metod badań kulturowych, dzięki którym możliwe będzie porównanie awangardy Wschodu i Zachodu oraz zrozumienie związku wybranych dzieł z przemianami zachodzącymi w Japonii. Istotne również wydaje się stworzenie modelu nadawcy i odbiorcy dzieł awangardowych poprzez zestawienie treści manifestów artystycznych zawierających projekty poszczególnych eksperymentatorów z badaniami odbioru dzieł na gruncie japońskim. Warto podkreślić, że sama idea manifestu awangardowego w Japonii ewoluowała wraz z rozwojem technologicznym kraju, przechodząc od drukowanych na łamach gazet kolaży (Terayama 1975: 84-85) do nagrań na YouTubie ${ }^{10}$. Zestawienie celów artystycznych twórców z rzeczywistym odbiorem ich dzieł może prowadzić także do wyodrębnienia mechanizmów powstawania kontrowersji (lub ich braku) wokół wybranego dzieła awangardowego. Przykładem mogą być szeroko krytykowane w japońskiej prasie ${ }^{11}$ działania Terayamy nastawione na zamanifestowanie obecności jego grupy artystycznej w przestrzeni miejskiej (Sorgenfrei 2005: 144). Projektując swojego „modelowego odbiorcę”, artysta nie wziął pod uwagę znużenia japońskiej publiczności lat 70. działaniami zakłócającymi porządek publiczny, przez co zamiast osiągać efekt przemiany widza pod wpływem głębokich przeżyć estetycznych, często spotykał się z krytyką i niezrozumieniem (Courdy 2001: 255-268).

Badając japoński film awangardowy, warto także odnieść się do metod badań historycznych, co z kolei pozwoli na umiejscowienie przemian sztuki awangardowej w szerszym kontekście przełomowych

łączenia się i rozłączania, tak, że można je opisać jedynie w odniesieniu do tego procesu".

${ }^{10}$ Back channel. 2014. bacc exhibition MAK Artist Interview-Makino Takashi, YouTube, https://www.youtube.com/watch?v=1AkM6Om6efo, dostęp: 31.08.2016.

${ }^{11}$ Sztuka performatywna Terayamy, nastawiona na wyjście do publiczności i zamianę przestrzeni miejskiej w scenę, była krytykowana przez takie gazety, jak „Asahi Shinbun”. 
wydarzeń w życiu narodu japońskiego. Pisząc o japońskiej awangardzie, trzeba podkreślić próbę rozrachunku artystów $\mathrm{z}$ powojenną traumą, wpływ traktatu ANPO na ruchy antymilitarne i kontrkulturowe, problemy ekonomiczne przełomu lat osiemdziesiątych oraz dziewięćdziesiątych, a także wpływ postępującej globalizacji na twórczość eksperymentatorów po 2000 roku. Jednym z ostatnich wydarzeń, które stało się katalizatorem dla działań artystów niezależnych i pionierów sztuki współczesnej, była katastrofa elektrowni w Fukushimie. Dyskurs krytyczny związany z tematyką tragedii z 2011 roku podjął między innymi Tomonari Nishikawa ${ }^{12}$.

Poszerzeniem analizy, oferującym możliwość zebrania unikalnego materiału, może być także zastosowanie metod badań antropologicznych. Świat działań artystów niezależnych i eksperymentalnych nadal pozostaje $\mathrm{w}$ ścisłym związku $\mathrm{z}$ bezpośrednim doświadczeniem pokazu przez widza oraz kontaktem $\mathrm{z}$ twórcą. Wiele dzieł audiowizualnych artystów japońskich jest przygotowywanych z myślą o projekcjach $\mathrm{w}$ salach kinowych lub w przestrzeniach wystawienniczych, przez co zapis cyfrowy filmu nie oddaje rzeczywistego zamysłu twór$\mathrm{cy}^{13}$. Mimo dostępności dużej ilości materiału wśród zasobów internetowych i faktu publikacji własnych dokonań przez młode pokolenia $\mathrm{w}$ sieci, uzyskanie pełnego obrazu nowego eksperymentu audiowizualnego na gruncie japońskim jest możliwe tylko poprzez bezpośrednią obserwację, wywiady i kontakty z reżyserami.

\section{Definiowanie awangardy}

Poszukując definicji współczesnych zjawisk na gruncie filmu japońskiego, odwołujących się do estetyki oraz tematyki poruszanej przez twórców awangardowych lat 70., warto umiejscowić niezależne eksperymenty audiowizualne w Kraju Kwitnącej Wiśni na tle ruchów światowych. Pisząc o roli filmu w wyrażaniu postulatów Awangardy, rozumianej jako ruch, Ryszard Kluszczyński zauważa, że jego „cał-

${ }^{12}$ Zob. przyp. 11.

${ }^{13}$ Przykładem takich obrazów mogą być dzieła Takashiego Makino (np. Space Noise, 2013-2014), przygotowywane jako kilka nakładających się na siebie obrazów, wyświetlanych jednocześnie z różnych projektorów i rzutowanych również na otaczające ekran ściany. Projekcjom często towarzyszy muzyka grana na żywo. Również obrazy filmowe Kazuhiro Goshimy (np. Shadowland, 2013) tworzone są z myślą o przestrzeni wystawienniczej, w której widz doświadcza także obszaru poza ekranem, wpisującego się w całość ekspozycji. 
kowita odmienność od sztuk dotychczas istniejących” i jego „dziewiczość" umożliwiała uczynienie go polem dla wdrożenia eksperymentów z formą oraz treścią (Kluszczyński 1989: 10-11), co można odnieść także do poszukiwań prowadzonych przez twórców japońskich. Niezależna sztuka audiowizualna w Kraju Kwitnącej Wiśni, odtwarzając założenia Awangardy, nadal charakteryzuje się nieustannym poszukiwaniem nowych rozwiązań, zaskakiwaniem widza i podejmowaniem aktualnych tematów społecznych. Ważną cechą awangardowych dzieł filmowych, która przetrwała do dziś w postulatach młodych eksperymentatorów, był także „zespołowy charakter produkcji", czyli kładzenie nacisku na kolektywizm poszukiwań artystycznych (Kluszczyński 1989: 17).

Z drugiej strony można przywołać rozważania Alicji Helman, która dzieli dokonania awangardy na dwie grupy - awangardę „właściwą" (twórczość m.in. Pudowkina, Eisensteina czy Wiertowa) oraz drugą awangardę francuską (np. L'Herbier, Epstein, Dulac) (Kluszczyński 1989: 29 [za:] Helman: 1976). Do drugiej z wymienionych kategorii badaczka zaliczyła także awangardę niemiecką oraz zjawiska występujące $\mathrm{w}$ innych krajach, uznając je za marginesowe dla rozwoju myśli awangardowej (Helman: 1976). Awangarda japońska, według kategoryzacji Helman wpisująca się w zakres drugiej grupy, miałaby być zjawiskiem niemającym znaczącego wpływu na kształt ruchu na Zachodzie. Trzeba przyznać, że bariery językowe nie sprzyjały przenikaniu treści z gruntu japońskiego na zachodni, a nieznający języka oryginału widz zagraniczny mógł najwyżej cieszyć się atmosferą przekazu, pozostając odcięty od pełnego zrozumienia treści. Obecnie, przy łatwym dostępie do narzędzi umożliwiających automatyczne tłumaczenie oraz znajomości języka angielskiego przez młode pokolenie japońskich twórców, bariera językowa zdaje się zanikać. Ponadto, jak zostało wspomniane wcześniej, nowy film eksperymentalny w Kraju Kwitnącej Wiśni, odcinając się od treści politycznych, oferuje widzowi głównie doświadczenie wizualne, którego przekaz może być zrozumiały bez względu na wcześniejsze przygotowanie lingwistyczne. Jednakże dokonania japońskiej awangardy, z całym swoim bogactwem znaczeń, odniesień oraz rozwiązań estetycznych, nie mogą być traktowane przez badaczy zachodnich jako marginesowe, a raczej jako nieodkryte i nieprzeniesione na grunt zachodni w odpowiednim czasie. Z kolei Ryszard Kluszczyński proponuje koncepcję jednej awangardy, rozumianej jako alternatywa dla instytucjonalizmu kina popularnego (Kluszczyński 1989), co pozwala na rezygnację z wartościowania dokonań twórców różnych kręgów kulturowych. Kluszczyński zauważa, że jeszcze inaczej na początki Ruchu 
patrzyli badacze tacy jak Le Grice czy Parker Tyler. Twierdzili oni, że awangarda klasyczna była wewnętrznie słabo zróżnicowana, a dopiero późniejsze formy filmowe pozwoliły w pełni rozwinąć jej potencjał (Kluszczyński 1989: 31). Podsumowaniem dyskusji może być komentarz Krystyny Wilkoszewskiej, która zauważa, że:

Można patrzeć na awangardę jako na przede wszystkim eksperymentatorstwo formalne, nakierowane na realizację wartości estetycznych, albo też jako na ruchy anarchizujące, zmierzające do obalenia artystyczno-estetycznych standardów [...] Za każdym razem, gdy do tuby zwanej kalejdoskopem wrzucimy awangardowy materiał, przy najlżejszej próbie obrotu pojawią się odmienne konstelacje. Nie wierzę, by istniała jedna formuła awangardy (Wilkoszewska 2006: 9).

Brak możliwości jednoznacznego i jednorazowego zdefiniowania, czym jest awangarda, ujawnia się w pełnym zakresie podczas badania twórczości artystów japońskich. Przemiany, jakie zaszły od czasów ulicznego teatru Terayamy do współczesnych eksperymentów z wykorzystaniem technik modelowania obiektów w 3D, powodują, że pozornie nie może być mowy o nowej awangardzie japońskiej. Jednakże, analizując komentarze artystów młodego pokolenia, ich źródła inspiracji oraz dążenia, można zauważyć, że dokonania mistrzów japońskiej awangardy są nadal obecne w twórczości młodych $^{14}$. Pomimo zamiłowania do nowoczesnych narzędzi wspomagających proces twórczy, młodzi eksperymentatorzy nadal próbują odnosić się do awangardowej idei wspólnoty twórców i łączyć się w kolektywy, stowarzyszenia oraz koła, których członkowie wzajemnie wspierają swoje poszukiwania artystyczne.

Wśród wielu koncepcji mających stanowić podsumowanie czasów historycznych awangard oraz określenie, czym współcześnie jest sztuka niezależna, pojawiają się także dyskusje na temat wyczerpania potencjału ruchów awangardowych. Rozważaniom towarzyszy próba odpowiedzi na pytanie, czy w „świecie po orgii” (Baudrillard 1993: 3), jak określał ponowoczesność Baudrillard, miały miejsce narodziny nowego kształtu świadomości artystycznej (Książek 2006: 77-78). Analizując postulaty oraz kierunki poszukiwań młodych japońskich twórców filmowego eksperymentu, można zauważyć, że zjawisko występujące na gruncie Kraju Kwitnącej Wiśni ma szansę stać się odpowiedzią na powyższe wątpliwości.

${ }^{14}$ Zob. s8cinema. 2014. 
Japoński film awangardowy i eksperyment audiowizualny: zakres materiału badawczego

Początki awangardowych form wyrazu w Japonii można wiązać z transferem założeń surrealizmu na grunt Kraju Kwitnącej Wiśni ${ }^{15}$ (Kletowski 2006: 22). Eksperymenty z materią filmową pojawiały się także w okresie klasycznym i mistrzowskim ${ }^{16}$ kina japońskiego (Loska 2009: 229-280). Jednakże zapowiedź estetyki awangardowej i nowatorskie podejście do tematów społecznych, pierwsze próby odrzucenia ciągłości przyczynowo-skutkowej oraz odwołania do poetyki snu przybrały na sile w połowie lat 60. Warto tutaj wspomnieć o Hiroshim Teshigaharze i jego mrocznych obrazach Tanin no kao (Twarz innego, 1966), Suna no ona (Kobieta z wydm, 1964) oraz Otoshiana (Pułapka, 1962), których głównym tematem jest przemiana głównego bohatera pod wpływem niepokojących, często nierzeczywistych wydarzeń.

Powstanie ruchów awangardowych, do którego doszło w latach 60., wiązało się z odrzuceniem przez młodych artystów wartości starszego pokolenia, jego oddania idei konformizmu (Loska 2013: 5253). Postacią, której działania wyznaczyły kształt eksperymentów podejmowanych zarówno na polu performatyki, jak i sztuki filmowej, był Shūji Terayama. Jego kontrowersyjne sztuki wystawiane w przestrzeni miejskiej, tworzone w myśl postulatu „wyjścia do widza”, oraz transgresyjne obrazy filmowe miały, w założeniu artysty, przekazywać wizję nowej, pozbawionej granic formalnych sztuki (Kiejziewicz 2016: 79-95). Terayama, podobnie jak scenarzysta i aktor Juro Kara, propagował na gruncie japońskim ideę wspólnotowości i kolektywizmu wśród artystów związanych z Ruchem, zachęcając do tworzenia stowarzyszeń oraz grup spędzających ze sobą czas także poza sceną. Pomysł reżysera wcielał w życie podczas swojej pracy także Shinya Tsukamoto (Mess 2005: 39-49), a echa potrzeby tworzenia kolektywów artystycznych są obecne także w postulatach młodego pokolenia artystów-eksperymentatorów po $2000 \mathrm{roku}^{17}$. Lata 60. i 70. dla japońskiej twórczości awangardowej były także momentem wyodrębnienia się głównych tematów i poruszanych zagad-

${ }^{15}$ Pierwszym japońskim filmem surrealistycznym jest Kurutta ippêji (Szalony paź, 1926) w reżyserii Teinosukei Kinugasy. Artysta starał się przenieść założenia zachodniego surrealizmu na grunt japoński.

${ }^{16}$ Jako przykład artysty wyróżniającego się poszukiwaniem autorskiego stylu i podejmowaniem eksperymentów z dziełem filmowym w okresie mistrzowskim kina japońskiego, może być przywołany Kenji Mizoguchi (1898-1956).

${ }^{17}$ Zob. s8cinema, Presentación... 
nień. W warstwie treści dzieł pojawiały się: krytyka polityki oraz norm społecznych, nowe ujęcia japońskiej tradycji kulturowej, ukazanie życia subkultur i ruchów kontrkulturowych, a także przekroczenia granic tabu związanego $\mathrm{z}$ przedstawianiem cielesności. W kontekście transgresji cielesnych, poza Terayamą, warto wspomnieć również o Toshiho Matsumoto, autorze filmu Żałobna parada róż (Bara no soretsu, 1969). W obrazie tym, ukazując życie członków bara $z \bar{o} k u^{18}$, reżyser doskonale oddał atmosferę japońskiej rewolucji seksualnej lat sześćdziesiątych (Berra 2010).

Lata 70. były czasem rozwoju eksperymentu filmowego. Poza Terayamą, w historii kina japońskiego zapisał się także Takahiko Iimura. Artysta poszukiwał powiązań między kinem a innymi sztukami, próbując przekroczyć granice definicji kina poprzez łączenie przeka$\mathrm{zu}$ audiowizualnego $\mathrm{z}$ malarstwem, instalacjami przestrzennymi i performansem (Ross 2014: 251-256). Natomiast pod koniec lat 80 . w Japonii pojawiła się nowa odmiana kina awangardowego, związana $\mathrm{z}$ antropomorfizacją społecznych fobii technologicznych pod postacią cyberpunkowych androidów. Wizje transgresji cielesnych związanych $\mathrm{z}$ przemianą jednostki $\mathrm{w}$ monstrum $\mathrm{z}$ ciała $\mathrm{i}$ stali oraz osadzenie czasu akcji filmów w dystopijnej przyszłości, można odnaleźć w obrazach Ishiiego Sogo, Shozina Fukui i Shigeru Izumiyi. Jednakże to Shinya Tsukamoto, reżyser Tetsuo - człowieka z żelaza (1989) oraz jego kontynuacji: Tetsuo II: Body Hammer (1992) i Tetsuo: The Bullet Man (2009), jest uważany za mistrza japońskiego niezależnego cyberpunka (Mess 2005: 236). Awangardowe środki wyrazu użyte $\mathrm{w}$ pierwszej z wymienionych produkcji stały się źródłem inspiracji dla następnych pokoleń twórców, a wizja przerażającego, mechanicznego ciała na stałe wpisała się w kanon cyberpunkowych wyobrażeń (Kiejziewicz 2014: 81-97).

Okres od połowy lat 90 . do 2000 roku w japońskiej awangardzie audiowizualnej był momentem przełomu. Japoński awangardowy cyberpunk ustąpił miejsca animacji ${ }^{19}$ (Helman 2010: 200-201) oraz produkcjom z pogranicza kina akcji i czarnej komedii ${ }^{20}$, natomiast zainteresowanie eksperymentem audiowizualnym prawie zanikło.

${ }^{18}$ Bara zōku (plemię róży) - japońskie określenie grup mężczyzn homoseksualnych, spotykających się w określonych klubach. Słowem najbliższym 'zōku' w języku polskim będzie 'subkultura'.

${ }^{19}$ Przykładem popularnej japońskiej animacji cyberpunkowej z lat dziewięćdziesiątych jest Duch w pancerzu (Ghost in the Shell, 1995) w reżyserii Mamoru Oshii.

${ }^{20}$ Przykładem takiego filmu może być Uzbrojony Yakuza (Full Metal Yakuza, 1997) w reżyserii Takashiego Miike. 
Dopiero nowe pokolenie artystów, które kończyło szkoły pod koniec lat 90. i na początku nowego stulecia wchodziło na rynek pracy, przywróciło zainteresowanie twórczością spoza głównego obiegu kultury. Wśród dzieł młodych eksperymentatorów należy przywołać dokonania Takashiego Makino i jego stowarzyszenia Collective [+]. Za pomocą abstrakcyjnych animacji przygotowanych z użyciem kamery cyfrowej, artysta zabiera widza w podróż do wnętrza wirujących kosmicznych pejzaży, mających zachęcać do kontemplacji i wyciszenia (Ross 2014). Tematykę powiązaną z wpływem ciał niebieskich na ludzką percepcję porusza również Takashi Ito, ukazując w swoim filmie The Moon (Księżyc, 1994) niepokojącą, surrealistyczną wizję świata zmienianego przez nieoczekiwane pojawianie się ziemskiego satelity (Kiejziewicz 2016: 150-152). Pisząc o młodym pokoleniu artystów, warto przywołać również takie postaci, jak Shinkan Tamaki, dla którego eksperyment wizualny stanowi studium ograniczeń percepcji widza (Tamaki 2016), oraz Tomonari Nishikawa, tworzący eksperymentalne zapisy dokumentalne $\mathrm{z}$ życia odwiedzanych miast (Martin 2008: 264-302). Jednym z artystów najbardziej zaawansowanych w swoich poszukiwaniach formy jest Kazuhiro Goshima, autor pełnometrażowego filmu eksperymentalnego Different Cities (Inne miasta, 2006). Swoją przygodę z filmem Japończyk rozpoczął już w latach 90., hobbystycznie tworząc minimalistyczne animacje komputerowe. Jednakże dopiero po 2000 roku artysta rozwinął swoją pasję związaną z analizą kształtu rozplanowania przestrzeni miejskiej i jej wpływu na człowieka (Vacheron 2012: 42-43), czemu dał wyraz w Innych Miastach oraz swoich późniejszych obrazach ${ }^{21}$. Przywołane wyżej dokonania młodych eksperymentatorów można zaliczyć do jednego z dwóch kierunków rozwoju współczesnego japońskiego eksperymentu - „nurtu technologicznego”. Jego przedstawiciele wyróżniają się doskonałym przygotowaniem technicznym do pracy z materią filmową, często osiągniętym dzięki uzyskaniu formalnego potwierdzenia kompetencji pod postacią dyplomów studiów wyższych.

Drugim nurtem dającym się wyodrębnić wśród twórczości młodego pokolenia eksperymentatorów jest „nurt ekologiczny”, rozwijany głównie przez japońskie artystki. Cechą odróżniającą ich sztukę audiowizualną od nurtu technologicznego jest wybór tematyki prac. Twórczynie skupiają się na ukazywaniu związków człowieka z otaczającym go środowiskiem i proponują przesłanie związane $\mathrm{z}$ pod-

${ }^{21}$ Wśród innych dokonań Goshimy można wymienić filmy i instalacje audiowizualne: Relative Position (2012), Shadowland (2013) oraz Looking and Listening (2015). 
kreśleniem poszanowania natury. Przedstawicielką nurtu, działającą wraz z Takashim Makino w grupie Collective [+], jest Rei Hayama. Artystka, odwołując się do swoich doświadczeń w dziedzinie sztuk plastycznych i wspomnień $\mathrm{z}$ dzieciństwa spędzonego na obserwacjach życia lasu, tworzy oniryczne kolaże audiowizualne, mające za zadanie zachęcić widza do refleksji nad znaczeniem natury (Delgado, Hinojosa 2014). Wśród artystek tworzących instalacje audiowizualne i filmy eksperymentalne poruszające podobną tematykę warto przywołać wspomnianą we wstępie Ai Hasegawę, zajmującą się ukazywaniem futurystycznych wizji alternatywnych rozwiązań biologicznych związanych z prokreacją ${ }^{22}$. W instalacji audiowizualnej I wanna Deliver a Dolphin (Chciałabym urodzić delfina, 2011-2013) poprzez realistyczne ukazanie na ekranie kobiety $\mathrm{w}$ trakcie porodu delfina (specjalnie przygotowanego na potrzeby instalacji robota) autorka zachęca widza do rozważenia etycznych aspektów hipotetycznej możliwości zostania przez kobietę matką zagrożonych gatunków.

Zakres materiału badawczego dotyczącego nowego japońskiego eksperymentu audiowizualnego stale się powiększa o nowe nazwiska i innowacyjne projekty, cały czas przesuwając granicę wyobraźni artystycznej. Dlatego też można uznać, że japońska awangarda w momencie pojawienia się nowego eksperymentu uległa przeobrażeniu, a dzięki kontynuacji zyskała nowe znaczenie, co umożliwia całościowe postrzeganie jej jako zjawiska ciągle żywego i ewoluującego $\mathrm{w}$ nowe formy.

\section{Podsumowanie: działania awangardowe w dobie nowych mediów}

Badaniom współczesnych zjawisk odwołujących się do estetyki awangardy, dokonań artystów działających na obrzeżach przemysłu kulturowego lub wprost określających siebie jako twórców awangardowych nieustannie towarzyszy pytanie o granice sztuki. W dobie Internetu definicja tego, czym jest wartość artystyczna, zmieniła się pod wpływem szerokiego dostępu do możliwości popularyzacji swoich dokonań przez wytwórców. Granice przesunęły się również pod wpływem popularności net artu, czyli sztuki Internetu, którą wyczerpująco opisała Ewa Wójtowicz w książce o tym samym tytule (Wójtowicz 2008). Działania artystów niezależnych są obecnie nieroze-

\footnotetext{
${ }^{22}$ Przywołane informacje dotyczące sztuki Ai Hasegawy zostały opublikowane przez Centrum Sztuki Wro w folderze wystawowym wydarzenia ECO EXPANDED CITY, które miało miejsce w 2016 roku.
} 
rwalnie związane z obecnością w Internecie i kreowaniem swojej popularności za pomocą publikacji filmów i kontaktów z fanami. Awangarda weszła do sieci na fali takich zjawisk jak Avant-Pop (Wójtowicz 2008: 41), będący przykładem wzajemnie przenikającej się kultury masowej i artystycznej awangardy w obszarze Internetu. Jak jednak zauważa Lew Manovich w artykule Awangarda jako software (Manovich 2010: 323-336), nowe pokolenie twórców działa podobnie jak poprzednie, korzystając $\mathrm{z}$ najnowszych zdobyczy kultury, z tym wyjątkiem, że tym razem narzędziem stały się komputery i dostęp do sieci.

Popularyzacja i pojawianie się w mediach treści awangardowych ma także inne oblicze, związane $\mathrm{z}$ transferem treści dawniej uznawanych za „niezależne” za pomocą mechanizmów komercyjnych. Przykład może stanowić tutaj sztuka Terayamy, który zyskał obecnie w Japonii status postaci „kultowej”. Jego wizerunek jest powielany w formie gadżetów przemysłu masowego (kubki, koszulki), co z kolei wiąże się ze zjawiskiem Midcultu, które trafnie opisał Umberto Eco, odwołując się do myśli Dwighta MacDonalda:

Midcult to dzieła, które wydają się mieć wszelkie cechy kultury idącej $\mathrm{z}$ duchem czasu, jednak w rzeczywistości stanowią parodię kultury, jej pauperyzację, zafałszowanie dokonane $\mathrm{w}$ celach komercyjnych (...). Midcultowi zarzuca się „wykorzystywanie” odkryć awangardy oraz „banalizowanie” ich poprzez sprowadzenie do przedmiotów konsumpcji (Eco 2010: 66-67).

W obliczu przejmowania przez kulturę masową zjawisk, które wcześniej stanowiły peryferia sztuki, tym trudniejsza staje się odpowiedź na pytanie o status dzisiejszych eksperymentów audiowizualnych. W gąszczu treści niezależnych, docierających do odbiorcy za pomocą mediów masowych, jedyną wskazówkę mogą stanowić manifesty młodych twórców, takich jak członkowie grupy Collective [+], którzy ogłaszają siebie kontynuatorami postulatów awangardowych mistrzów ${ }^{23}$.

\section{Bibliografia}

Baudrillard, John. 1993. The Transparency of Evil: Essays on Extreme Phenomena. Londyn, Nowy Jork: Verso.

${ }^{23}$ Zob. s8cinema. 2014. 
Berra, John. 2010. Japan. Directory of World Cinema. Bristol: Intellect Books.

Courdy, Keiko. 2001. Antonin Artaud's Influence on Terayama Shūji: Stanca Scholz-Cionca (red.). Japanese Theatre and the International Stage. Boston: Brill, 255-268.

Delgado, Monica, José S. Hinojosa. 2014. Interview: Rei Hayama, desistfilm, http://desistfilm.com/interview-rei-hayama/, dostęp: 10.09.2016.

Eco, Umberto. 2010. Apokaliptycy i dostosowani. Komunikacja masowa a teorie kultury masowej. Tłum. Piotr Salwa. Warszawa: Wydawnictwo W.A.B.

Foster, Hal. 2010. Powrót realnego. Awangarda u schyłku XX wieku. Tłum. Mateusz Borowski, Małgorzata Sugiera. Universitas: Kraków.

Helman, Alicja, Agnieszka Kamrowska. 2010. Autorzy kina azjatyckiego. Kraków: Wydawnictwo RABID.

Helman, Alicja. 1976. Historyczna rola awangardy okresu niemego. Karol Lubelski, Władysław Banaszkiewicz (red.). Z dziejów awangardy filmowej. Katowice: Wydawnictwo UŚ, 9-18.

Karolak, Nikodem. 2014. Demitologizacja dzieciństwa Terayamy Shūjiego na przykładzie jego utworów parabiograficznych, Gdańskie Studia Azji Wschodniej 5 (2014), 137-151.

Karolak, Nikodem. 2013. Portret mistrza: Shūji Terayama - Kaliban i Prospero japońskiej sztuki awangardowej, Japonia Online, http://japonia-online.pl/article/146, dostęp: 23.01.2016.

Karolak, Nikodem. 2015. Terayama Shūji - japoński Prospero czy Kaliban? Konotacje z twórczością dramaturgiczną Tadeusza Kantora, Konteksty 1, 2 (2015), 374-383.

Kiejziewicz, Agnieszka. 2016. Enter the Metaphysical Cosmos. The Visualizations of the Universe in Japanese Experimental Cinema, Magazyn antropologiczno-społeczno-kulturowy "Maska" 29 (2016), 147-156.

Kiejziewicz, Agnieszka. 2014. Shinya Tsukamoto i wyobraźnia cyberpunkowa. Sebastian Jakub Konefał (red.) Anatomia wyobraźni. Gdańsk: Gdański Klub Fantastyki, 81-97.

Kiejziewicz, Agnieszka. 2016. Skandalista Shūji Terayama - Pomiędzy postulatami a odbiorem sztuki mistrza japońskiej awangardy, Zeszyty Naukowe Towarzystwa Doktorantów Uniwersytetu Jagiellońskiego. Nauki Humanistyczne 12, 1 (2016), 79-95.

Kletowski, Piotr. 2006. Sfilmować duszę. Mała historia kina japońskiego. Kraków: Biblioteka Centrum manggha.

Kluszczyński, Ryszard W. 1989. Film i wielka awangarda. Ryszard W. Kluszczyński (red.). Film awangardowy $w$ Polsce i na świecie. Łódź: Łódzki Dom Kultury, 9-65. 
Loska, Krzysztof. 2013. Nowy film japoński. Kraków: Universitas.

Loska, Krzysztof. 2009. Poetyka filmu japońskiego. Kraków: Wydawnictwo RABID.

Manovich, Lew. 2010. Awangarda jako software. Tłum. Iwona Kurz. Kwartalnik filmowy 35, 36 (2010), 323-336.

Martin, Katy. 2008. Interview with Daichi Saito and Tomonari Nishikawa, Asia Experimental Media Issue, EXIS International Film and Video Festival, 264-302, http://katymartin.net/assets/katy-martin-saito-nishikawainterview-dec08.pdf, dostęp: 1.04. 2016.

Mersch, Dieter. 2010. Teorie mediów. Tłum. Ewa Krauss. Warszawa: Wydawnictwo "Sic!".

Mess, Tom. 2005. Iron Man. The Cinema of Shinya Tsukamoto. Godalming: FAB Press.

Ridgely, Steven C. 2010. Japanese Counterculture. The Antiestablishment Art of Terayama Shüji. Minneapolis: University Of Minnesota Press.

Ross, Julian. 2014. Projection as Performance: Intermediality in Japan's Expanded Cinema: Lucia Nagib, Anne Jerslev (red.). Impure Cinema. Intermedial and Intercultural approaches to film. Londyn: I.B. Tauris, 251-256.

Ross. Julian. 2014. Interview: Takashi Makino, filmcomment, http://www.filmcomment.com/blog/interview-takashi-makino/, dostęp: 14.08.2016.

s8cinema. 2014. Presentación Colectivo [+] Tokyo. Takashi Makino, Rei Hayama e Shinkan Tamaki, YouTube, https://www.youtube.com/watch?v = S-UWJRVu77c, dostęp: 12.08.2016.

Sorgenfrei, Carol F. 2005. Unspeakable Acts: The Avant-garde Theatre of Terayama Shüji and Postwar Japan, Honolulu: University of Hawaii Press.

Terayama, Shūji. 1975. Manifesto, The Drama Review 19, 4 (1975), 84-85. Wiek awangardy, 2006, Liliana Bieszczad (red.). Kraków: Universitas.

Wójtowicz, Ewa. 2008. Net art. Kraków: Wydawnictwo RABID.

Vacheron, Joel. 2012. Kazuhiro Goshima: After the Metabolic Cities. 12th Biennial of Moving Images in Geneva, 42-43, http://joelvacheron.net/wordpress/wpcontent/uploads/2007/11/Goshima-12th-BIM2.pdf, dostęp: 10.08.2016. 


\begin{abstract}
Exploring changes in the Japanese avant-garde film. From Terayama to the audiovisual experiment after the year $\mathbf{2 0 0 0}$

The presented article covers the subject of changes in the Japanese avant-garde film through the cinematographic epochs. The aim of the paper is to introduce the reader to the methodology, definitions and the range of the research concerning Japanese avant-garde cinema. The author also presents the importance of the conducted research for the Polish film research. What is more, she tries to answer the question of how the avant-garde film should be perceived in the era of mass-media.
\end{abstract}

Keywords: Avant-garde, Japanese film, Japanese cinema, experimental film, new experiment, Takashi Makino, Shūji Terayama, audiovisual experiment, Avant-pop 